\title{
THE DEVELOPMENT OF SUBJECT MODULE OF THE PRINCIPAL STRING INSTRUMENT (BEGINNER) AT THE MUSIC ARTS STUDY PROGRAM, FBS, UNESA
}

\author{
Vivi Ervina Dewi, Harpang Yudha Karyawanto, Dhani Kristiandri \\ Universitas Negeri Surabaya \\ E-mail: vividewi@unesa.ac.id
}

\begin{abstract}
This study program is under the Department of Art, Drama, Dance, and Music, Faculty of Languages and Arts, Universitas Negeri Surabaya. This program uses the Independent Learning Curriculum. A course on the principal string instrument (beginner) is featured in the third semester. However, there are still many issues with its execution. Due to the COVID-19 pandemic, students must study at home. Thus, this scenario affects students' capacities. As a result, this research will show the development and effectiveness of a subject module of the principal string instrument (beginner) at the Faculty of Languages and Arts, Universitas Negeri Surabaya. This study uses the ADDIE learning design model (Analysis-Design-Develop-Implement-Evaluate). Learning products research produces a learning module designed to help students improve their violin playing skills, especially in the principal string instrument (beginner). Developing the principal string instrument (beginner) learning module begins with a needs analysis based on observation, field studies, and literature. Each stage of product development involves analysis, design, development, implementation, and evaluation. The design results were assessed by material, language, and graphic experts and revised. After revisions, the product was tested on students of the music arts study program, Universitas Negeri Surabaya. The results are packaged as learning modules for music arts lecturers and students. The development research results show that using products in learning modules can improve violin playing skills. The t-test value of 0.000 indicates that the experimental and control groups differ significantly.
\end{abstract}

Keywords: Development, Module, Learning, Violin.

\section{INTRODUCTION}

Art education is an education that prioritizes aesthetics or beauty. The implementation of art education includes several significant aspects, including creativity, skills, and sensitivity. This statement is also in line with Hajar Pamadhi (2012: 3), who stated that art education is a means of developing children's creativity and aesthetic education, which aims to restore education to a sense of beauty.

Music education is one of the most paramount parts of implementing art education in Indonesia. This is in harmony with Plato (in
Djohan Salim, 2005: 175), which stated that in education, music occupies the highest position since no single discipline can get into the soul and accompany it with tiered abilities beyond rhythm and harmony. In other words, music education is the only discipline that trains the sensitivity of taste and soul. The implementation of music education in Indonesia can be seen from various levels of education, be it formal, non-formal, or informal levels of education. One level of formal education that implements music education is the higher education level. 
Universitas Negeri Surabaya is one of the formal educations in higher education that implements music education. This can be seen from several study programs that offer musical expertise. One of them is the music arts study program.

The music arts study program is one of the new study programs established in 2015 at the Department of Art, Drama, Dance, and Music, Faculty of Languages and Arts, Universitas Negeri Surabaya. This study program has 10 educators or lecturers with their respective expertise. The existence of this study program can be seen from the number of students who have graduated in 2019, 2020, and 2021. In addition, this study program also shows its existence through various awards and achievements of its students at the local, national, and international levels. Meanwhile, the number of students enrolling in the study program is increasing from year to year. This music art study program is the only (pure) music study program in East Java that is based on classical music. The curriculum implemented in this study program is the Independent Learning Curriculum which consists of practical courses and theoretical courses.

One of the practical courses of the music arts program, which is based on an Independent Learning Curriculum, is the principal string instrument (beginner). The course load is three credits with a duration of 150 minutes. The course is carried out when students are in the third semester.

Based on the preliminary study that has been carried out through observations, it was found that each student has very diverse skills or abilities. The difference in these abilities can be seen from the playing of scales, etude, and repertoire of each student. It means that one student with another student plays the scales, etude, and repertoire with different levels. This is caused by several factors, including ineffective exercise duration, inappropriate individual learning methods, and so on. Therefore, lecturers must implement effective learning strategies. Besides, lecturers can also provide several alternative scales, etudes, and songs to students so that their abilities can improve, especially for students who are still lacking in skills and abilities.

Based on the preliminary study that has been carried out, it was found that the scales, etude, and songs given by the lecturer to students who still have less skill are not effective enough in improving skills or abilities with rapid progress. In addition, the current condition of the COVID-19 pandemic requires students to study from home so that it has an impact on the progress of increasing students' abilities or skills that cannot be seen significantly. This is due to the nature of the implementation of the practical courses that should be done through face-to-face mentoring. Therefore, effective learning modules are needed and adapted to the conditions of the COVID-19 pandemic. Meanwhile, the implementation of the Independent Learning Curriculum requires students to learn quickly and effectively. This can be seen from the implementation of the previous curriculum with the practice level of the main instrument as many as 6 mandatory levels turned into 4 mandatory levels in the implementation of the Independent Learning Curriculum.

Obstacles and problems that exist in the process of lecturing the principal string instrument (beginner) at this time cause a great influence on the development of students' abilities and skills. Therefore, this study attempts to present an alternative or new formula for an effective learning module that is adapted to current conditions through a subject module of the principal string instrument (beginner). Based on this description, this research is intended to describe the development and examine the effectiveness and quality of a subject module of the principal string instrument (beginner). 


\section{BACKGROUND \\ Development}

This study is Research and Development or $\mathrm{R} \& \mathrm{D}$ that is a process used to develop and validate products used in the education sector as well as test their effectiveness. The research and development method is a scientific way to research, design, produce, and test the validity of the products that have been processed (Sugiyono, 2015: 30). Based on the description stated above, instead of testing theory, development research aims to develop the theory of the study. In this study, the product that is going to be produced is a subject module of The Principal String Instrument (Beginner).

\section{Learning}

One aspect that is expected to occur in the teaching and learning activities is effective learning. Effective learning (Reiser, 1996: 14) is good learning that students like, and they acquire specific skills, knowledge, and attitudes. Besides, learning is effective if there are changes in cognitive, affective, and psychomotor aspects. Meanwhile, there are four criteria for effective learning Reigeluth (, 2007: 28) as follows: accuracy in mastery, performance speed, learning transfer rates, and retention rates. In addition to Slavin (in Djamarah, 2006:105), four aspects determine the effectiveness of learning: the quality of learning, the suitability of the level of learning, incentives, and time.

The learning process can work well if models, methods, strategies, and techniques of learning are applied. The learning methods and models almost have similarities in the teaching and learning process. Further, the difference between the learning method and the model (Suyono and Hariyanto, 2015: $146)$ is there are systematic syntax and procedures in the learning model. Briefly, the learning model tends to emphasize complex systematic procedures, which include the structures of the entire learning process.

\section{Teaching Materials}

Teaching material is one of the most important components in the teaching and learning activity. The teaching material is all forms of materials used by teachers or educators in carrying out the teaching and learning activity. These materials can be in the form of either written or unwritten materials. Students might be able to learn a competency coherently and systematically through the teaching materials so that they can master all competencies in a complete and integrated manner (Majid, 2008: 173). Moreover, according to the Faculte de Psychologie et des Sciences de l'Education Universite de Geneve, the teaching material grouping is as follows: written (printed), audiovisual, electronic, and integrated interactive (media mix). The teaching material in this development research is a practice module of the principal string instrument (beginner). Besides, this type of teaching material is written (printed) media.

\section{Violin Instrument}

Throughout the history of music (Hickok, 1975: 5), composers or songwriters have written musical works to be played by various instruments used in various numbers, combinations, and groupings. Thus, one of these instruments is a soprano violin. The violin has an important role in an orchestra because it is the main play of the orchestra performance.

\section{METHOD}

\section{Development Type}

The type of research used was development research that developed a product in the form of a module that contains several techniques of playing string musical instruments such as a violin applied to the product for the needs of lecture teaching materials. 


\section{Development Model}

The development model of this study used was ADDIE Learning Design Model (Analysis Design Develop Implement Evaluate) with the consideration that the model should be applied to develop a system-oriented instructional model product in order to produce targeted, effective, and dynamical learning. According to Mollenda (2003: 35), ADDIE model design aims to be a guide in developing both tools and infrastructure of a learning program ineffectively, dynamically, and supporting the learning performance itself.

\section{RESULTS AND DISCUSSION Product Development Process Results}

The product used in this research and development consists of five steps, namely: 1) Analysis; 2) Design; 3) Development; 4) Implementation; and 5) Evaluation. The results of the initial product development consist of the analysis to development steps. The results of these steps are in the following below.

\section{Analysis Results}

At this stage, there were two steps carried out by researchers, and those were literature review and field study. The field study aimed to determine the condition of the music program, students, facilities, and infrastructure and analyze the needs of lecturers and students in the learning process. The method used in this stage was observation and interview.

\section{Observation Results}

The observation was conducted at the research location that was the Music Arts Study Program, Department of Drama, Dance, and Music, Languages and Arts Faculty, the State University of Surabaya (UNESA). The observation was carried out to 10 students of the music arts study program who took the violin major as a test subject. Based on the observa- tion results, it can be concluded that there were ten students who took the subject of the principal string instrument (violin) for beginner level with different music playing skills. All students who took this course have a violin as a musical instrument and a stand-part. In addition, the music studio used in this lecture is highly supportive. Evidently, the music studio has been set into soundproofing also an air-conditioned room. The principal string instrument (violin) subject for beginners was carried out in the third semester. This practical course is usually held face to face once a week with a course load of 3 credits and credit hours of $2 \frac{1}{2}$ (150 minutes).

Based on the preliminary study carried out, it was found that the scales (musical notes), etude, and songs given by lecturers to the unskilled students were not effective enough to improve skills or abilities quickly. Moreover, the current Covid-19 pandemic condition requires students to study from home and influences the progress of increasing students' abilities or skills that were not indicated significantly. Due to the implementation of this practical course, it is required to be conducted through face-to-face assistance. Therefore, an effective learning module is literally needed and should be adapted to the current condition that is the Covid-19 pandemic. Besides, the implementation of an independent learning curriculum (Kurikulum Kampus Merdeka) is required and expected to support the students to learn quickly and effectively. It can be seen from the implementation of the previous curriculum with 6 mandatory levels of the basic instrument practice. However, the basic instrument practice levels in the independent learning curriculum implementation is currently reduced to 4 mandatory levels.

\section{The Results of a Literature Review}

A literature review was conducted in order to explore the information needed in de- 
veloping products which were obtained from various literatures. In this research and development, a literature review was conducted on the practical material of the violin instrument to determine the material tendencies to be developed. Based on the results of the literature review, the basic practice of the violin instrument was going to be used as the material in this research and development. The material in the basic practice of the violin instrument includes scales (musical notes), techniques of playing the violin, etude, and repertoires of the song. Furthermore, the collection of learning material was carried out. Moreover, the results of literature review were used to convey the materials in an appropriate way based on the ability level and characteristics of young students.

\section{Design Results \\ Results of Plan Development}

A plan development is focused on the students' competence which should be achieved in the main stringed instrument (violin) course at an early level. The competencies are students can play scales, violin techniques, etude, and songs' repertoire well.

The product is in the form of a subject module of The Principal String Instrument (Beginner) for the students and lecturers in the Music Study Program. Besides, there is a CD (Compact Disc) about the practice and discussion in the module to make the publication easier. This module aims to help the teaching and learning process. It mainly covers various materials, such as course observation, scales, violin techniques, etude, and songs' repertoire.

\section{Development Results}

\section{Assessment Instrument Validity}

Before the assessment instrument of the product is used, the validity should be checked by the validator. He is Agus Suwahyono, S.Sn., M.Pd. The assessment instru- ment validity to assess the product or the output is in the form of psychomotor. The validator assessment was based on the rubric, the criteria of the assessment instrument. After that, the validator assessed the form of messages and comments.

Based on the instrument validity, it can be concluded that the product assessment instrument can be used to assess the product under development.

\section{Results of the Product Assessment by Experts}

Before the product is used, it should be stated valid by the product validators. They are Moh. Sarjoko, S.Sn., M.Pd., Hespi Septiana, S.Pd., M.Pd., and Nanda Nini Anggalih, S.Pd., M.Ds. The product validity is used to assess the product whether is proper for the trial. The validity was tested by the experts of materials, languages, and graphics.

Based on the product validity by the expert, it can be concluded that the product can be used for field trials without any revision. The score from the material validators is 58 , the language validator is 60 , and the graphic validator is 61 .

\section{Product Trial Results}

The limited trial for the product development is only for five students who are taking the music study program. The trial was conducted in two meetings for 90 minutes each. Meanwhile, the evaluation is based on the limited trial that can be revised that in technical material to play violin should be added with bowing technique.

\section{Product Revision \\ Product Revision Based on the Lecturer's Suggestion}

The suggestion given by the lecturer in the classroom is the additional material about the fingering technique. The purpose is for the students to understand the fingering tech- 
nique in detail while playing the violin. Moreover, they can play the repertoire with the right fingering.

\section{Product Revision Based on the Field Trial Results}

After the revision, the suggestion from the lecturer, and the result of the limited trial, the product was implemented to ten students in the experimental group. It was conducted once a week for 120 meetings and lasted for five weeks.

\section{The Last Product Review Analysis of Product Feasibility}

After the revision, the product was tested in the Music Art Major via Zoom Platform with five participants from the experimental group and five participants from the controlling group.

Based on the field test, the product is feasible to be implemented. Therefore, the purpose of this study has been achieved is to produce a module for a subject module of The Principal String Instrument (Beginner). Besides, the product is stated effective to be used in the teaching and learning for of a subject module of The Principal String Instrument (Beginner) with the same learners' characteristics.

\section{Results of the Product Effectively Test}

To analyze the output in the form of skill to play violin from the product use used ttest. Before the data analysis using t-test, some requirement for this study is needed. Those are normalizing the data and making sure the data variance in the experimental group is homogenous. The normality test and the homogeneity from the pre-test and posttest showed that the data was normal and homogeny. Therefore, the t-test was continued. T-test was used to analyze the result of the data from the study that is a free sample test. It is used to find out the significant difference of students' violin skills which were taught using the developmental product and not using the product simultaneously. The manova test calculation used Levene's Test and counted using SPSS 23.0 software. The decision criteria (Pallant, 20100: 287) is when sig. $<0.05$, then it can be concluded that there is a significant difference between the groups in the dependent variable. Meanwhile, the t-test was divided into two stages of analysis as follows:

\section{Pretest t-test}

The first stage of the analysis was the pretest t-test. It was done to find out whether there is a mean difference between the experimental group and control group from their skill in playing violin during the pretest.

Based on the statistical analysis of SPSS software, it can be found that the t-test result of both groups during the pretest has a significant value of 0.848 . The significant value shows $>0.05$, so it can be stated that there is no significant difference in the pretest result in playing violin for both groups. Based on the result of the pretest t-test, it can be concluded that there is no significant difference in students' skill to play violin whether they used the product development or not.

\section{Post-test t-test}

The next stage of the analysis is the posttest t-test. It is used to find out whether there is a mean difference between the experimental group and control group from the students' skill while playing violin during the post-test.

Based on the statistical analysis using SPSS software, it was found that the t-test result in the experimental group and control group has sig. value 0.000 . It shows $<0.05$, so it can be said that there is a difference in the result of the post-test. In the other words, the result of the students' skill in playing the violin is different based on the post-test result. Based on the post-test t-test, it can be con- 
cluded that there is a significant difference between the students who were taught using the product development and not.

\section{CONCLUSIONS}

Based on the result of this study and the development which has been done, it can be concluded into some point which is a subject module of The Principal String Instrument (Beginner) is started by doing need analysis through observation, field study, and review of the literature. The product creation is done through stages of analysis, design, development, implementation, and evaluation. The design result was assessed by the experts of material development, language, and graphics and they tried to get some revision. After that, the product is tested on the students who are taking the Music Art Study Program in Universitas Negeri Surabaya. The result of the implementation was covered in the form of a learning module for the lecturers and students. The learning module was stated effective because it can improve the students' ability in playing the violin. It is proven with the sig, 0.000 using t-test, so it can be said that the experimental group is different from the control group significantly.

\section{REFERENCES}

Hickok, R. (1975). Music appreciation. New York: Addison-Wesley Publishing Company, Inc.

Mollenda, M. (2003). In search of the ellusive ADDIE model. Pervormance improvement, 42 (5), 34-36. Submitted for publication in A. Kovalchick \& K. Dawson, Ed's, Educational Technologi: An Encyclopedia. Copyright by ABC- Clio, Santa Barbara, CA.

Reigeluth,M., dan Alison A. Carr-Chellman. (2007). Instructional Design Theories and Models. Lawrence Erlbaum Associates, Mahwah, New Jersey. London

Reiser, Robert A dan Dick, Walter. 1996. Instructional Planning: A Guide For Teachers. United States of America: Electronic Publishing Services, Inc.

Sugiyono. (2015). Metode Penelitian \& Pengembangan. Bandung: Alfabeta.

Suyono., \& Hariyanto. (2015). Implementasi belajar dan pembelajaran. Bandung: PT Remaja Rosdakarya.

Djohan Salim. (2005). Psikologi musik. Yogyakarta: Best Publisher.

Hajar Pamadhi. (2012). Pendidikan seni. Yogyakarta: UNY Press.

Majid, Abdul. 2008. Perencanaan Pembelajaran: Mengembangkan Standar Kompetensi Guru. Bandung: PT Remaja Rosdakarya.

Djamarah, Zain. (2006). Strategi Belajar Mengajar. Jakarta : Rineka Cipta. 